\title{
El Régimen Fiscal de los bienes de la Iglesia durante el siglo IV
}

\author{
Fiscal Treatment of Church Patrimony During \\ the fourth century
}

\author{
NARCISO SANTOS YANGUAS*
}

\begin{abstract}
RESUMEN
ABSTRACT

El patrimonio de la Iglesia, aunque remonta en sus orígenes a las comunidades cristianas de los 3 primeros siglos, no tendría un reconocimiento oficial hasta la época de Constantino.

A continuación lo consolidaría el emperador Constancio II mediante la aplicación de exenciones fiscales. Dicho patrimonio se incrementaría a través de la apropiación de los templos paganos y de sus bienes, a pesar de la fase de regresión que supone la época de Juliano (361-363).

A lo largo del siglo IV el Código

Teodosiano documenta la situación de las propiedades eclesiásticas y su fiscalidad.

\section{PALABRAS CLAVE:}

Patrimonio de la Iglesia, exenciones fiscales, apropiación de templos paganos,

Constantino, Constancio II, Código Teodosiano.

The patrimony of the Church, whose origins can be traced back to the Christian communities of the first three centuries, will not officially reckoned until Emperor Constantine $s$ times.

Emperor Constantius II would then consolidate it by applying fiscal exemptions.

Despite the fact that Emperor Julian s rule (361-363) can in itself explain a degree of diminution, the truth is that the said patrimony was increased by the appropriation of pagan temples and the goods contained in them. In the fourth century the Theodosian Codex lists ecclesiastical properties and their fiscal treatment.

\section{KEY WORDS:}

Patrimony of the Church, fiscal exemptions, appropriation of pagan temples, Constantine, Constantius II, Theodosian Codex.
\end{abstract}

* Universidad de Oviedo. E-mail: nsantos@uniovi.es 


\section{INTRODUCCIÓN}

La configuración definitiva del patrimonio de la Iglesia no tendría lugar exclusivamente a partir de los años intermedios del siglo IV, coincidiendo por tanto con su reconocimiento como religión oficial (religio licita) y su afianzamiento en el marco de la política general (y religiosa) llevada a cabo por el Estado y la administración romanos ${ }^{1}$.

Dicho fenómeno arranca, en sus orígenes, de los primeros años de eclosión del cristianismo a mediados de la primera centuria de nuestra era, momento que corresponde a la formación de los parámetros que iban a definir a la Iglesia como doctrina ideológica en el ámbito del mundo romano².

Es por ello que, a lo largo de los 3 siglos siguientes, estos primeros atisbos de patrimonio eclesiástico se irían configurando poco a poco ${ }^{3}$ hasta desembocar definitivamente en su consolidación y organización a lo largo de la centuria que va a ser objeto prioritario de nuestra consideración ${ }^{4}$.

De esta manera, aunque el Codex Theodosianus constituya la principal fuente de información de dicho proceso, especialmente como recopilación jurídica de las diferentes etapas y facetas del mismo, habremos de recurrir igualmente a otros documentos escritos de la Antigüedad (tanto del Alto como del Bajo Imperio), que nos informan sobre los orígenes y primeras circunstancias que caracterizan este hecho (acaparamiento de bienes por parte de las Iglesia cristiana y regulación fiscal de dichas propiedades en el marco de la organización económica del Imperio $)^{5}$.

Entre tales fuentes de información hemos de tener en cuenta, por ejemplo, las referencias recogidas perfectamente desde un punto de vista imparcial (pagano) en las Res Gestae de Amiano Marcelino acerca de algunos de los avatares del cristianismo en su época, en especial durante los años que transcurren entre Constancio II y Teodosio, sin olvidar el período de interregno que, desde la perspectiva del paganismo romano, supondría el reinado de Juliano ${ }^{6}$.

De cualquier forma hemos de tener en cuenta que no todo el empeño de la Iglesia estaría centrado en su enriquecimiento como institución sino que su actividad iba a dirigirse igualmente a menudo a la protección de los más necesitados de

1 SANTOS, N.: «Ammiano Marcelino, Teodosio y el cristianismo», HAnt, 20 (1996) pp. 437 ss.

2 SORDI, M.: Los cristianos y el Imperio Romano, Madrid, 1988, pp. 149-150.

$3 \mathrm{BUCCl}, \mathrm{A}$ :: «Le radice storiche della formazione giuridica del concetto di bene ecclesiastico», ApoIlinaris, 77 (2004) pp. 357 ss.

${ }^{4}$ GAUDEMET, J.: «L'Église et l'État au IVe siècle», Studi in onore A.Biscardi, Milán, 1983, 4, pp. 75 ss.

5 BUENACASA, C.: «La propiedad eclesiástica según el Codex Theodosianus. Estado preliminar», Congreso Internacional La Hispania de Teodosio, Segovia, 1997, pp. 31 ss.

6 Momento en que las tradicionales creencias en la adivinación y la magia, propias de la sociedad pagana de Roma, contemplaron la posibilidad de poder renacer de nuevo. Cf. BOUFFARTIGUE, J.: «L empereur Julian et I etrusca disciplina», La divination dans le monde italique. 9, Etrusca Disciplina, Tours, 2005, pp. 27 ss. 
la sociedad romana, contribuyendo así a solucionar, aunque fuese únicamente de forma parcial, los problemas que la pobreza arrastraba?.

Y ello a pesar de que esta forma de actuar de la Iglesia cristiana nada tendría que ver con la institución (benéfica) constituida por los alimenta de Trajano ${ }^{8}$, cuyo ámbito de vigencia temporal se extendería durante más de dos siglos, desde dicho emperador hasta la época de Constantino ${ }^{9}$.

\section{ANTECEDENTES}

Los primeros indicios de concentración y acumulación de bienes por parte de la Iglesia remontan a los mismos orígenes del cristianismo, puesto que en diversos pasajes del Nuevo Testamento (Hechos de los Apóstoles en especial) se especifica con claridad la solicitud a los cristianos de aportaciones dinerarias y de todo tipo con el fin de distribuirlas después entre los miembros de las comunidades menos favorecidos ${ }^{10}$.

De esta manera, en el transcurso de la primera centuria de nuestra era, en concreto durante los años del reinado de Nerón y, sobre todo, de Domiciano, con la presencia de simpatizantes y adeptos a la religión cristiana entre algunos miembros de la gens Flavia aumentarían sin duda las aportaciones económicas al patrimonio de la Iglesia ${ }^{11}$.

Avanzando en el tiempo, sabemos que, durante el siglo II, este proceso de incremento de los bienes de la Iglesia discurriría parejo a la actividad de los laicos en la vida asociativa del cristianismo primitivo, de acuerdo con la existencia de «iglesias domésticas», como serían, entre otros, los casos de Lugdunum (Lyon) y de Vienne en el sur de Galia ${ }^{12}$.

Por ello podemos afirmar que la Iglesia se nos presenta desde un primer momento como una comunidad organizada jerárquicamente, es decir como una asociación cuyos miembros tenían funciones y competencias diferentes en el marco de

7 ROUGÉ, J.: «Aspects de la pauvreté et des remèdes aux IVe-Ve siècles», $A A R C, 8$ (1990) pp. 227 ss.

8 VEYNE, P.: «Les alimenta de Trajan», Les empereurs romains d Espagne, París, 1965, pp. 163 ss. Ver igualmente GONZÁLEZ ROMÁN, C.: «Trajano, optimus princeps: a propósito de los alimenta», Trajano, óptimo príncipe. De Itálica a la corte de los Césares, Sevilla, 2004, pp. 173 ss.

9 GONZÁLEZ ROMÁN, C.: «Problemas sociales y política religiosa. A propósito de los rescriptos de Trajano, Adriano y Antonino Pío sobre los cristianos», MHA, 5 (1981) pp. 227 ss., y «Melitón de Sardes y las relaciones entre paganismo y cristianismo a fines del reinado de Marco Aurelio", In memoriam A.Díaz Toledo, Granada-Almería, 1985, pp. 181 ss.

10 SORDI, M.: Los cristianos y el Imperio Romano, pp. 169 ss.

11 PERGOLA, P.: «La condamnation des Flaviens «chrétiens» sous Domitien. Persécution ou represion à caractère politique? », MEFR, 90 (1978) pp. 407 ss. Cf. BARZANO, A.: «Plinio il Giovane e i cristiani alla corte de Domiziano», RSCl, 36 (1982) pp. 408 ss., y SANTOS, N.: «Domiciano, el senado y los cristianos», Helmantica, 61 (2010) pp. 97 ss.

12 DE CHURRUCA, J.: «Confesseurs non condamnés à mort dans le procès contre les chrétiens de Lyon I année 177», VChr, 38 (1984) pp. 257 ss. 
la vida cotidiana (y, como consecuencia de ello, necesitaban disponer de un patrimonio de cierta entidad para poder llevar a cabo ese tipo de actividades).

Así pues, al contrario de lo que sostienen a menudo quienes consideran que el peligro que el Estado romano veía en el cristianismo era de naturaleza política y que juzgan la falta perseguida en los cristianos ante todo como una falta de asociación ilícita (collegium illicitum) ${ }^{13}$, la historia de las relaciones entre el cristianismo y el Imperio revela más bien que los romanos, aunque conocerían muy pronto las estructuras asociativas de los cristianos, atacarían a la nueva religión, al menos hasta los tiempos del emperador Valeriano, como falta religiosa individual, no colectiva.

Ya durante el siglo III, al margen de las prohibiciones de Septimio Severo contra el proselitismo cristiano ${ }^{14}$, sobresale el segundo edicto de persecución de Valeriano, que condenaba a muerte a los obispos, viniendo acompañadas dichas medidas de la confiscación de los bienes de las comunidades cristianas, sin especificar demasiado en qué consistía dicho patrimonio ni el alcance del mismo ${ }^{15}$.

De esta manera, la primera condena formal de los cristianos como Iglesia, lo que suponía un tratamiento particularizado y diferenciado, reservado exclusivamente a los miembros de la jerarquía eclesiástica y a los laicos, se refleja en los edictos anticristianos de Valeriano ${ }^{16}$.

Sin embargo, esta prohibición del derecho de reunión (y asociación) para el colectivo de los cristianos, así como la confiscación de las propiedades eclesiásticas, vendría seguida de inmediato (años 257/260) por el primer reconocimiento oficial de la licitud de la Iglesia (el edicto de Galieno) ${ }^{17}$.

Este hecho supone que, pocos años después de los edictos anticristianos de Valeriano, la cancillería de Galieno emitiría una nueva orden con vistas, por un lado, a la devolución de los bienes confiscados a la Iglesia, por otro a la entrega de los lugares de culto y, finalmente a la recuperación de los cementerios por las comunidades cristianas ${ }^{18}$.

Dicha actuación imperial tal vez no sería más que una respuesta como compensación a los efectos catastróficos que los edictos de Valeriano habían ocasionado al embargar los bienes del patrimonio de la Iglesia ${ }^{19}$.

13 SORDI, M.: Los cristianos y el Imperio Romano, página 169.

${ }^{14}$ Ver, entre otros, LEONE, M.: «ll provvedimento di Settimio Servero contro i cristiani», Studi Manni, Roma, 1980, pp. 1317 ss. 197 ss.

5 SANTOS, N.: “Valeriano y los cristianos», Espacio, Tiempo y Forma (HaA Antigua), 8 (1995) pp.

16 KERESZTES, P.: «Two Edicts of the Emperor Valerian», VChr, 29 (1975) pp. 81 ss.

17 TOYOTA, K.: «The Edict of Toleration of the Emperor Gallienus (en japonés con resumen en ingles)», JCS, 28 (1980) pp. 88 ss.

18 SANTOS, N.: El cristianismo en el marco de la crisis del siglo III en el Imperio Romano, Oviedo, 1996, pp. 171-176.

19 Posiblemente en estas décadas del siglo III dicho patrimonio todavía no se alimentaría, al menos en cantidades significativas, a partir del montante económico procedente de las herencias. 
Así pues, es posible afirmar, aunque resulte paradójico, que el cristianismo sería condenado como religión durante los primeros años de su existencia y reconocido como Iglesia, de modo que las medidas negativas de Valeriano contra él constituirían el paso previo, doloroso pero a la postre necesario, para el reconocimiento por parte de Galieno.

\section{CONSTANTINO Y EL RECONOCIMIENTO DE LOS BIENES DEL PATRIMONIO ECLESIÁSTICO}

Un paso sustancial a este respecto lo va a suponer la política religiosa de Constantino, ya en el siglo IV, quien, tras apagarse los ecos de la Gran Persecución de Diocleciano ${ }^{20}$, concedería libertad absoluta a la Iglesia, como asociación lícita, para disponer libremente de su patrimonio y poder así aumentarlo.

Este hecho se manifestaría por medio del edicto (más bien acuerdos) de Milán en una primera fase ${ }^{21}$, que incluía la predisposición favorable de Licinio a devolver la libertad de culto a las comunidades cristianas.

Sin embargo, se dispondría a este respecto de un magnífico precedente, constituido por la devolución de la libertad de culto a los cristianos por parte de Galerio ${ }^{22}$.

El ciclo se completaría en estos primeros momentos a través de la emisión de sendos documentos epistolares acerca de las subvenciones estatales a las iglesias cristianas y la exención clerical de las funciones públicas.

Pero es que, además, la política de tolerancia (con la normativa imperial correspondiente) con respecto al colectivo de los cristianos se vería completada por parte del emperador Constantino mediante la aplicación de una serie de medidas ${ }^{23}$.

De ellas algunas estaban destinadas a favorecer, ante todo, la existencia física de las comunidades cristianas a través de la exención fiscal de los impuestos ${ }^{24}$.

Junto a ello se explicitaba igualmente la exención de las funciones públicas por parte de los miembros del clero ${ }^{25}$, de acuerdo con lo que recoge Eusebio de Cesarea en estas dos cartas emitidas por dicho emperador en el transcurso del año $313^{26}$. 235 ss

20 FERNÁNDEZ, G.: «Causas y consecuencias de la Gran Persecución», Gerión, 1 (1983) pp.

21 Lact., De mort.persec. 48.1-13.

22 Euseb., HE 8.17.1-10.

${ }_{23}$ Sobre la política de Constantino con respecto a la Iglesia cristiana ver, entre otros, BUCKHARDT, J.: «Constantin und die Kirche», Konstantin der Grosse, Darmstadt, 1974, pp. 19 ss.

24 Euseb., $H E$ 10.6.1-5.

25 Euseb., HE 10.7.1-2. Cf. DUPONT, C.: «Décisions et textes constantiniens dans les oeuvres d Eusèbe de Césarée», Viator, 2 (1971) pp. 1 ss.

26 RABELLO, A. M.: «I privilegi dei chierici sotto Costantino», Labeo, 16 (1970) pp. 385 ss. 
De esta manera Constantino llevaría a sus últimas consecuencias el reconocimiento definitivo del cristianismo (y de la Iglesia) en el marco político del Imperio, hecho que se haría más palpable a partir del año 320.

En el ámbito de las prerrogativas económicas el primer edicto que facultaba a la iglesia para poder recibir donaciones y herencias se fecha en el año 321: el emperador se mostraría espléndido al entregar, tanto de la parte correspondiente a sus bienes como de la del fisco, numerosos donativos a la comunidad cristiana ${ }^{27}$.

Se enmarcan igualmente en este contexto las obras de reparación de un conjunto de centros de culto cristianos, así como la construcción de algunos otros de nueva planta.

Todo ello se completaría con la asignación a los mismos de un patrimonio con fondos suficientes para su mantenimiento, así como de un cuerpo sacerdotal a su servicio (disposición imperial del año 324), sin contar los abundantes objetos litúrgicos de oro y plata, destinados especialmente a las iglesias de Roma.

Estas prerrogativas económicas se complementarían a su vez con las exenciones fiscales de que disfrutaron los bienes patrimoniales eclesiásticos, en el mismo contexto que las concedidas a las propiedades imperiales ${ }^{28}$.

Tales beneficios se harían extensivos a todos los miembros de la jerarquía eclesiástica, lo que en el fondo supondría una especie de estatuto jurídico privilegiado para los mismos frente al resto de la ciudadanía (incluidos los adeptos del cristianismo sin jerarquía).

Finalmente, desde el punto de vista social, hay que destacar las disposiciones imperiales relativas a las manumisiones eclesiásticas por parte de los componentes del clero de la Iglesia ${ }^{29}$.

Ello supondría que, además del reconocimiento religioso, se ponían las bases para que en adelante la Iglesia fuese considerada ya como una institución lícita y legal, que podría disponer libremente de su propio patrimonio, favoreciendo por otro lado a los componentes de la jerarquía de la misma ${ }^{30}$.

\section{LA LABOR DEL EMPERADOR CONSTANCIO II}

La época de Constancio II (y la legislación que emana de su cancillería) constituye un período especialmente notable con vistas a la configuración y protección

27 Tenemos constancia de ello en el inventario de bienes eclesiásticos reseñado en el Liber pontificalis.

${ }_{28}$ Se identifican, sobre todo, con la iugatio, es decir el impuesto normal sobre las propiedades territoriales.

${ }_{29}$ Esta tentativa de aproximación a los principios sociales propuestos por el cristianismo hunde sus raíces en la valoración realizada por los estoicos con respecto a la esclavitud en tiempos de Adriano.

30 BRIEGER, Th.: «Constantin der Grosse als Religionspolitiker», Konstantin der Grosse, Darmstadt, 1974, pp. 56 ss. 
del patrimonio eclesiástico, a lo que hemos de añadir además el permiso concedido por la autoridad imperial para la apropiación (con visos de expolio) de los templos y santuarios paganos por parte de la Iglesia ${ }^{31}$.

A este respecto podemos afirmar que los hijos de Constantino continuarían, con algunos leves retoques, la política religiosa de su progenitor, prosiguiendo por tanto la tarea de favorecer económicamente a la Iglesia cristiana, que aquél había iniciado.

De este modo en el año 353 Constancio II y Constante (durante los años de Imperio compartido) darían publicidad a una ley dirigida a todos los obispos de las distintas provincias del Imperio mediante la cual se renovaba la exención a favor de los clérigos y de los iuvenes (que para algunos investigadores hay que identificar con los diáconos mientras que para otros serían los catecúmenos) con respecto a los munera civilia ${ }^{32}$.

Eso suponía que se eximía a los integrantes de dichos colectivos de los servicios civiles de cualquier tipo que resultaban obligatorios para los restantes habitantes de las ciudades provinciales.

Junto a ello quedaban al margen igualmente de la denominada collatio lustralis (CÓDIGO TEODOSIANO XVI.2.10) ${ }^{33}$, impuesto destinado a gravar a los comerciantes, para que, con los beneficios obtenidos, la Iglesia pudiera facilitar la caridad a los pobres ${ }^{34}$.

Ambos emperadores se encargarían de liberar a los miembros del sacerdocio cristiano de los impuestos extraordinarios, así como de la prestación de las parangariae, consideradas como la provisión de vehículos para el cursus publicus.

Sin embargo, otros autores, como M. SARGENTI ${ }^{35}$ por ejemplo, piensan que, en el contexto del lenguaje jurídico del Bajo Imperio, parangariae haría referencia a los animales (caballos y/o bueyes, es decir las acémilas) destinados a las comunicaciones más difíciles y cuya prestación resultaba por ello más molesta y gravosa para los ciudadanos.

Tales exenciones se harían extensivas igualmente a las mujeres y a los hijos, así como a los libertos y a los esclavos, de manera que con ello se pretendería dar un fuerte impulso a que muchos abrazaran las órdenes sacerdotales.

De cualquier forma, en el momento en que Constancio II se hace con el mando único del Imperio su actividad con respecto a los cristianos, siguiendo muy

31 BUENACASA, C.: «La constitución y protección del patrimonio eclesiástico y la apropiación de los santuarios paganos por parte de la Iglesia en la legislación de Constancio II (337-361)», Pyrenae, 28 (1997) pp. 229 ss.

32 DE BONFILS, G.: «Alcune riflessioni sulla legislazione di Costanzo II e Costante», AARC, 5 (1983) pp. 299ss

33 DUPONT, C.: «Les privilèges des clercs sous Constantin», RHE, 62 (1967) página 746.

34 Ver, entre otros, STANOJEVIC, O.: «La protezione dei poveri: influsso del cristianesimo o politica antifeudale? », AARC, 7 (1988) pp. 495 ss.

35 «Aspetti e problemi dell opera legislativa dell imperatore Giuliano», AARC, 3 (1979) página 357. 
de cerca la línea de actuación trazada por su padre, se centraría fundamentalmente en afianzar los privilegios de todo tipo (y, por descontado, económicos) de la Iglesia ${ }^{36}$.

Para ello emitiría sendas constitutiones, que en un principio afectaban exclusivamente al clero romano, dadas las particulares circunstancias religiosas por las que estaba atravesando la capital del Imperio en aquellos momentos (hemos de recordar que el emperador había enviado al exilio al papa-obispo de Roma Liberio, sustituyéndolo por el archidiácono Félix, más dócil a acatar las órdenes imperiales).

Es posible pensar, por tanto, que el motivo de la promulgación de ambos edictos o leyes no sería otro que el de recompensar la lealtad del máximo representante de la Iglesia, al tiempo que se trataba de mostrar a los sacerdotes de la comunidad cristiana cuál de los dos obispos estaba legitimado por el poder romano ${ }^{37}$.

I. La primera de tales constitutiones (CÓDIGO TEODOSIANO XVI.2.13 [año 357]), dirigida a Leoncio en cuanto prefecto de la ciudad de Roma (máxima autoridad civil y responsable último de que en la ciudad se cumplieran las disposiciones emanadas de la cancillería imperial), debido a su vaguedad apenas encierra importancia para nuestros propósitos, ya que únicamente establece que se respeten con firmeza y diligencia los privilegios concedidos a la Iglesia en Roma, sin especificar en qué consistían (a este respecto no debemos olvidar que tanto Constantino como Constancio II habían otorgado ya con anterioridad numerosas inmunidades al clero de la ciudad de Roma) ${ }^{38}$.

II. Por su parte en la segunda de ellas, dirigida al obispo-papa Félix (CÓDIGO TEODOSIANO XVI.2.14), que algunos investigadores fechan en el año $356^{39}$ mientras que otros llevan su datación a un año después ${ }^{40}$, se hace hincapié nuevamente en el hecho de que los clérigos deben quedar dispensados de los servicios obligatorios, así como de cualquier otro impuesto (inmunes semper a censibus et separati ab huiusmodi muneribus).

Algunos investigadores, como FERRARI DALLE SPADE, han querido observar en esta última expresión (hace ya 50 años) la exención del pago del impuesto fundiario; sin embargo, posiblemente haga mención a los impuestos extraordinarios, puesto que en ninguna de sus partes la constitutio menciona la exención de la iugatio.

36 GIUFFRIDA, C.: «L amministrazione imperiale ai tempi di Costanzo Il», Studia Storica, 23 (1982) pp. 647 ss.

37 CRACCO RUGGINI, L.: «Felix Temporum Reparatio: realtà socio-economiche in movimento durante un ventennio di regno (Costanzo II Augusto, 337-361 d.C.)», L Église et I Empire au IVe siècle, Vandoeuvres-Génève, 1989, pp. 179 ss.

38 DUPONT, C.: «Les privilèges des clercs sous Constantin», pp. 741-743.

39 BOVE, L.: «Inmunitá fondiaria dei chiese e chierici nel Basso Impero», Synteleia V.ArangioRuiz, Nápoles, 1964, página 891, nota 16.

40 FERRARI DALLE SPADE, G.: Immunità ecclesiastiche nel diritto romano imperiale, Milan, 1956, página 132. 
Junto a ello se especifica, en este documento imperial, que los sacerdotes dedicados a las actividades comerciales y cuantos trabajaban para ellos seguirían estando exentos del pago de la collatio lustralis, todo ello con el objetivo de que los clérigos contasen con recursos suficientes para atender al cuidado de los más necesitados $^{41}$.

De la misma manera los talleres y cuadras de ganado propiedad de los sacerdotes se hallaban protegidos con la inmunidad ante las tasas e impuestos que recaían sobre ellos.

Por último la disposición imperial se hace extensiva igualmente a las mujeres, hijos, libertos y esclavos, así como a sus respectivas familias.

\section{LAS EXENCIONES PATRIMONIALES DE LA IGLESIA}

Esta situación tan privilegiada para los componentes de la Iglesia en su conjunto, y en especial para quienes formaban parte de la jerarquía de la misma, se vería recortada en los momentos finales del reinado de dicho emperador: así, en el 359 Constancio II convocó un concilio en Rímini para que los obispos occidentales aprobaran el símbolo de fe arriano ${ }^{42}$.

Los hechos clave del mismo se desarrollaron de la siguiente forma: el cónclave se reunió bajo la presidencia de Restituto, obispo de Cartago, y, con el asentimiento de todos los obispos arrianos asistentes (unos 80 ), votaron unánimemente solicitar al emperador que les concediera la completa inmunidad de los impuestos ordinarios para los fundi eclesiásticos (iuga, quae videntur ad ecclesiam pertinere) ${ }^{43}$.

A este respecto hemos de tener presente que la decisión sería acordada tanto por los obispos católicos como por los arrianos, dado que el interés era mutuo, puesto que el desempeño de las funciones episcopales en aquellos momentos comenzaba a ser perseguido por la elite aristocrática del Imperio, que veía en el episcopado una alternativa al cursus honorum de la administración civil.

La carrera eclesiástica ofrecía unas expectativas muy halagüeñas para la promoción social, motivo por el que numerosos obispos pertenecían a la clase senatorial y, como resultado de ello, estaban obligados a combinar sus actividades religiosas con las concernientes a la administración de unos patrimonios personales de cierta entidad.

En este contexto se comprende perfectamente el contenido del canon 12 del concilio de Serdica (celebrado unos 15 años antes que el de Rímini), en el que se

${ }^{41}$ CARON, P. G.: «Natura giuridica del sistema dei rapporti fra Stato e Chiesa nell impero romano e nell impero bizantino", Studi in onore di C.Sanfilipo, Milan, 1982, 2, pp. 61 ss.

42 PIETRI, Ch.: «La politique de Constance II: un premier "césaropapisme» ou I imitatio Constantini? », L Église et I Empire au IVe siècle, pp. 169-170.

${ }^{43}$ BOVE, L.: «Inmunita fondiaria dei chiese e chierici nel Basso Impero», pp. 891-894. 
dispone que los obispos no pasen demasiado tiempo en sus latifundios personales con el fin de no descuidar el buen gobierno de sus comunidades de fieles ${ }^{44}$.

Sin embargo, esta última petición episcopal no lograría la confirmación y sanción imperiales, pese a lo cual Constancio II daría a conocer su parecer por medio de una constitutio que se promulgó poco tiempo después (CÓDIGO TEODOSIANO XVI.2.15, del 359 o del 360?).

Además, todo este conjunto de disposiciones imperiales se ampliaría a otras materias que incumbían igualmente a los privilegios de la Iglesia: por ejemplo en el fragmento inicial de dicha promulgación se recortan los privilegios que se habían otorgado a los clérigos en materia comercial, disponiendo que tanto ellos como los copiatae, también denominados fossores ${ }^{45}$, únicamente quedarían eximidos del pago del impuesto comercial en las transacciones destinadas a cubrir sus necesidades de tipo personal.

En la segunda parte de este mismo documento imperial se toma una decisión con respecto a la petición formulada por los obispos, cuya interpretación no es coincidente en todos los investigadores: por ejemplo, FERRARI DALLE SPADE ${ }^{46}$ considera que el emperador se negaría a conceder la inmunidad que le solicitaban los clérigos cristianos, mientras que Lucio BOVE ${ }^{47}$ interpreta, creemos que con acierto, que en el contenido de dicha ley se distinguía entre los bienes que se hallaban bajo la administración de la Iglesia y aquellos que integraban el patrimonio personal de obispos y clérigos.

De esta manera, mientras que los bienes de los miembros del orden sacerdotal debían someterse ad universa munia sustinenda translationesque faciendas era preciso exceptuar (praeter) los correspondientes a la Iglesia.

Su hipótesis se basa en el hecho de que la exención del impuesto fundiario no sería una norma común en el momento en que se celebró el cónclave de Rímini, por lo que en el mismo sería reclamada oficialmente por parte de los obispos ${ }^{48}$.

Tal vez la explicación a esta confusión se halle en el hecho de que a través de una constitutio, posiblemente obra de Constantino, el emperador había concedido con anterioridad a las posesiones inmuebles de la Iglesia una inmunidad en cuanto a los impuestos idéntica a la que beneficiaba a los terrenos de la res privata y, de acuerdo con la cual, dichas propiedades únicamente abonarían la iugatio-capitatio (CÓDIGO TEODOSIANO XI.1.1) $)^{49}$.

${ }^{44}$ BAJO, F.: «Iglesia y legislación imperial en el Bajo Imperio», A cidade e o mundo: romanización e cambio social, Xinzo de Limia, 1995, pp. 103 ss.

45 CONDE, E.: Los fossores de Roma Paleocristiana (Estudio iconográfico, epigráfico y social), Ciudad del Vaticano, 1979.

46 Inmunità ecclesiastiche nel diritto romano imperiale, página 127

47 «Inmunità fondiaria dei chiese e chierici nel Basso Impero», página 892.

48 PIETRI, Ch.: «La politique de Constance II: un premier «césaropapisme» ou I imitatio Constantini? », página 171 .

49 GAUDEMET, J.: «La législation religeuse de Constantin», RHE, 33 (1947) pp. 25 ss. 
El primer problema que se nos plantea al analizar este documento se relaciona con su atribución temporal a un emperador o a otro (Constantino o Constancio II).

Para FERRARI DALLE SPADE hay que ubicarlo cronológicamente, de acuerdo con la datación tradicional, en el año 31550; sin embargo BOVE no participa de esta opinión:

- en primer término porque, según él, ni Eusebio de Cesarea, ni Sócrates, ni Sozomeno, ni Teodoreto, obispo de Ciro, se hacen eco del mismo en sus escritos; $y$,

- además, porque considera que, de los personajes que aparecen mencionados en el texto, Eusebio, Arsaces y Daciano resultan perfectamente conocidos en el reinado de Constancio II, mientras que no se conoce ningún Procliano para la época de Constantino.

Así pues, este autor cree que dicha ley sería fruto directo de la labor legislativa de Constancio II, aceptando la proposición, ya planteada como alternativa por Mommsen, del año 360 como fecha ${ }^{51}$.

Por su parte algunos otros investigadores, como J. DURLIAT ${ }^{52}$, se inclinan igualmente por esta segunda fecha, aunque asegurando que serviría para sancionar una costumbre que se venía practicando desde algún tiempo antes.

A este respecto hemos de tener en cuenta que si los historiadores eclesiásticos de la Antigüedad no mencionan dicha orden imperial durante el reinado de Constantino, tampoco lo hacen durante el correspondiente a Constancio II ${ }^{53}$.

Tal vez haya que pensar por ello que una disposición tan favorable y beneficiosa para la Iglesia solamente puede hallar explicación en el momento en que el patrimonio con el que ésta contaba era todavía escaso.

De acuerdo con la documentación de la época las primeras donaciones que lleva a cabo Constantino con respecto a la Iglesia consistieron en terrenos que pertenecían a la res privata, en cuyo suelo deberían edificarse las iglesias cristianas (el caso más relevante, conocido y significativo es sin duda el de San Juan de Letrán en Roma).

Así pues, a través de esta constitutio el primer emperador cristiano confirma los privilegios que comportaban estas tierras, con anterioridad pertenecientes al Estado y que en la actualidad se hallaban en manos de la Iglesia ${ }^{54}$.

50 Inmunità ecclesiastiche nel diritto romano imperiale, página 127.

51 «Inmunità fondiaria dei chiese e chierici nel Basso Impero», pp. 887-890.

52 Les finances publiques de Dioclétien aux Carolingiens (284-889), Sigmaringen, 1990, página 56, nota 160 .

53 MAZZA, M.: «Costanzo II, i costantinidi e gli storici ecclesiastici. Una "Constantinopolitan Connection?"», $A A R C, 10$ (1995) pp. 85 ss.

54 JOANNOU, P. P.: La législation impériale et la christianisation de I Empire romain (311-476), Roma, 1972, pp. 15-18. 
Por ello creemos que atribuir dicha promulgación a Constancio II sería un error, puesto que su actuación tras el concilio de Rímini trataría de poner fin a un confusionismo que reinaba sobre este problema, y cuyos orígenes solamente pueden hallarse en una ley edictada con suficiente anterioridad para que, en el intervalo de tiempo transcurrido para su aplicación, surgieran numerosos problemas sociales y de otra índole.

Además, cuando Constancio II, tras el cónclave de Rímini, decide acerca de la inmunidad de las propiedades de la Iglesia dirige su proclama a Tauro, prefecto del pretorio para Italia y África.

Sin embargo, si este emperador hubiera firmado en Constantinopla, el día 18 de enero del 360, la ley recogida en el CÓDIGO TEODOSIANO como XI.1.1, el destinatario debería haber sido Helpidio, a la sazón prefecto del pretorio de Oriente, pues ese era el proceder que observamos, entre otros casos, en la constitutio emitida en esa misma ciudad solo unos días después, en concreto el 4 de febrero (CÓDIGO TEODOSIANO XI.24.1).

De cualquier forma, la petición de los obispos reunidos en Rímini parece responder perfectamente a los problemas prácticos que se derivarían de la aplicación de dicha ley, puesto que se encontrarían ante el hecho de que, con posterioridad a su emisión, el patrimonio de la Iglesia habría crecido ampliamente a causa de las donaciones privadas, así como de las herencias testamentarias ${ }^{55}$.

Es por ello que, sin duda la confusión acerca del status jurídico de dichas donaciones, así como el interés por poner bajo la protección de una ley tan beneficiosa los patrimonios personales de cada clérigo, sería la causa que había conducido a semejante petición.

Y los emperadores que siguieron a Constancio II parecen haber confirmado igualmente el sentido restrictivo de dichas inmunidades ${ }^{56}$.

De otra manera no es posible entender cómo, en tiempos de Teodosio II (año 424), se considera como algo excepcional el dispensar temporalmente a la Iglesia de Tesalónica del pago de la iugatio-capitatio (CÓDIGO TEODOSIANO XI.1.33).

A partir de aquí podemos deducir que ese comportamiento favorable de exención fiscal ya no sería la norma general aplicada, y en consecuencia que el resto de las iglesias estarían obligadas a cumplir con el pago de dicho impuesto ${ }^{57}$.

Junto a ello nos encontramos con el hecho de que otras fuentes antiguas nos informan acerca de diferentes casos en los que este tipo de inmunidad se extiende a un grupo reducido de iglesias locales ${ }^{58}$.

55 Sobre el patrimonio de la Iglesia de Roma donado por Constantino resultan muy interesantes los comentarios de PIETRI, Ch. [Roma Cristiana. Recherches sur I Église de Rome, son organisation, sa politique, son idéologie de Miltiade à Sixte III (311-440), Roma, 1976, 1, pp. 84-90].

56 DAHYOT-DOLIVET, G.: «L Église à I époque impériale (313 à 590)», Apollinaris, 55 (1982) pp. 846 ss.

57 FERRARI DALLE SPADE, G.: Inmunità ecclesiastiche nel diritto romano imperiale, pp. 128-130.

58 Recogidos por BOVE, L. [«Inmunità fondiara dei chiese e chierici nel Basso Impero», pp. 896- 
Así pues, a partir de la documentación de que disponemos en la actualidad, es posible deducir que los impuestos sobre los que se extendía la exención fiscal serían única y exclusivamente los extraordinarios y las superindictiones, de acuerdo con lo que se desprende del contenido de una constitutio de Constancio II, fechada en el año 343 (CÓDIGO TEODOSIANO XI.75.1), en la que se afirma:

«privatas possessiones nostras ab universis muneribus sordidis placet esse inmunes, neque earum conductores nec colonos vel ad extraordinaria munera vel superindictiones aliquas conveniri.»

\section{PATRIMONIO DE LA IGLESIA Y APROPIACIÓN DE LOS SANTUARIOS PAGANOS}

Sin lugar a dudas resulta evidente que Constancio II iría más allá que su padre en la política de protección a los miembros de la Iglesia, y no solo a los representantes de su jerarquía, puesto que sabemos que beneficiaría tanto a los católicos como a los arrianos ${ }^{59}$.

En el Codex Theodosianus no encontramos disposición alguna en la que se haga una distinción clara en función de la fe que cada uno de los sacerdotes profesase, así como tampoco ninguna ley dirigida expresamente contra los herejes.

Se explicaría este hecho, de acuerdo con su política religiosa, porque el emperador obligaría a firmar tantas profesiones de fe arrianas como creyó necesarias, siendo desterrados quienes no accedieran a ello a diferentes centros urbanos de las provincias del Imperio, donde no gozarían de ningún privilegio ${ }^{60}$.

En esta misma línea de actuación el emperador Constancio II, ya como gobernante único, llevaría a cabo una política agresiva tanto contra los paganos como contra los judíos (CÓDIGO TEODOSIANO XVI.8.6-7).

Y ello a pesar de que tales disposiciones de la cancillería imperial serían demasiado generales y ambiciosas como para poder llegar a aplicarse de forma eficaz e inmediata ${ }^{61}$.

De esta manera, aunque el cristianismo había experimentado sin duda grandes avances en el marco de la sociedad romana, la situación todavía no era propicia para que esta política alcanzara los frutos deseados.

Sin embargo, serviría en cualquier caso para concienciar a los ciudadanos romanos de que era preciso ser cristiano para progresar en el Imperio, preparando

902]. Cf. KAPLAN, M.: Les propriétés de la Couronne et de I Église dans I Empire bizantin (Ve-Vle siècles), París, 1976, página 77.

59 DUPONT, C.: «Privilèges des clercs sous Constantin», página 751.

60 SALZMAN, M. R.: «The Evidence for the Conversion of the Roman Empire to Christianity in Book 16 of the Theodosian Code», Historia, 42 (1993) pp. 362 ss.

61 PIETRI, C.: «La politique de Constance II: un premier «césaropapisme» ou I imitatio Constanti$n i ? »$, página 163. 
de esta manera el camino para el gran triunfo que sobre el paganismo supondría el reinado de Teodosio62.

La legislación antipagana de los emperadores aparece recogida tanto en el Codex Theodosianus como en el Codex lustinianus bajo el título de paganis, sacrificiis et templis: en el primero aparecen 25 constitutiones y en el segundo 10, de ellas 6 recogidas ya en el anterior.

Se trata, por consiguiente, de 29 leyes que cubren el período de tiempo que transcurre desde el año 331 hasta el reinado de Justiniano $\left.\right|^{63}$.

De todos estos elementos jurídicos romanos se deduce que los hijos de Constantino emprenderían una persecución hostil contra el paganismo, de cuyas consecuencias tenemos noticias a través de numerosos autores antiguos como SOZOMENO (Historia Eclesiástica 3.17), TEODORETO DE CIRO (Historia Eclesiástica 5.21.2) y SímMACO (Relationes 3.4).

A este respecto la batalla legislativa parece haberse llevado a cabo a niveles distintos:

- en un primer momento se atacarían las prácticas de culto paganas, hecho que tendría su origen ya en tiempos de Constantino ${ }^{64}$;

- con posterioridad se actuaría contra los templos y espacios sagrados paganos, es decir contra lo que representaba la base económica sobre la que descansaba dicha religión ${ }^{65}$;

- y un tercer nivel de actuación estaría constituido por la persecución de las personas (hasta el reinado de Teodosio sin noticia alguna de ello).

Con respecto a los ritos paganos sabemos que en el año 341 Constante y Constancio II ordenarían que cesaran los sacrificios en honor de los dioses: cesset superstitio, sacrificiorum aboletur insania (CÓDIGO TEODOSIANO XVI.10.2) ${ }^{66}$.

Algunos años después (al parecer en el 353) Constancio II, preocupado porque el usurpador Magnencio había permitido los sacrificios nocturnos en Galia, promulgaría una nueva ley con vistas a la abolición de los mismos (CÓDIGO TEODOSIANO XVI.10.5) ${ }^{67}$.

Y esta política se completaría en el momento en que dicho emperador (año 356), con el fin de intimidar a cuantos se habían atrevido a contravenir sus órde-

62 PASCHOUD, F.: «ll cristianesimo nell Impero romano», AFLM, 19 (1986) pp. 25 ss.

63 GAUDEMET, J.: «La législation antipaïenne de Constantin à Justinien», CS, 11 (1990) pp. 449 ss.

64 BARNES, T.D.: «Constantine s Prohibition of Pagan Sacrifice», AJPh, 195 (1984) pp. 69 ss.

65 BONAMENTE, C.: «Sulla confisca dei beni mobile dei templi in epoca costantiniana», Costantino il Grande, Macerata, 1992, 1, pp. 171 ss.

66 SALZMAN, M. R.: "Superstitio in the Codex Theodosianus and the Persecution of Pagans", VChr, 41 (1987) pp. 179-180.

67 DE GIOVANNI, L. (Costantino e il mondo pagano. Studi di politica e legislazione, Nápoles, 1989, página 138) considera por ello que los sacrificios diurnos serían lícitos. 
nes, establecería como castigo la pena de muerte para los infractores (CÓDIGO TEODOSIANO XVI.10.6) ${ }^{68}$.

Sin embargo, resultan mucho más significativas y llamativas las disposiciones imperiales relativas a los templos y lugares de culto paganos ${ }^{69}$.

Así, por ejemplo, ya al inicio de su reinado en común, Constante y Constancio II decidieron la clausura de los templos urbanos, mientras que los rurales podían continuar abiertos con el único objetivo de servir a los juegos (CÓDIGO TEODOSIANO XVI.10.3).

Los problemas derivados de esta constitutio se desprenden sin duda de la dificultad que supondría para el Estado romano garantizar la impunidad de quienes atentasen contra los templos paganos rurales.

De cualquier forma la persistencia del paganismo se atestigua en la parte oriental del Imperio como mínimo hasta la época de Justiniano $\mathrm{I}^{70}$, de acuerdo con lo que se desprende del hecho de que tanto él como sus antecesores en el trono se verían en la necesidad de legislar en contra de las prácticas paganas, muy arraigadas todavía en los medios rurales (CÓDIGO JUSTINIANO I.11.7 (año 451); I.11.8 (472?); I.11.9 (sin fecha); I.11.10 (sin fecha) $)^{71}$.

Contando, por tanto, con esta legislación imperial favorable, en numerosas ocasiones serían los propios obispos locales, y no el Estado, quienes llevarían a cabo las destrucciones de los santuarios paganos de sus comunidades.

Algunos investigadores consideran a este respecto ${ }^{72}$ que la Iglesia actuaría de acuerdo con la iniciativa del Estado, de manera que la destrucción de los templos paganos no constituiría en realidad un esfuerzo organizado por parte de los miembros de la jerarquía sacerdotal cristiana.

Sin embargo, los testimonios correspondientes al reinado de Constancio II parecen probar lo contrario; y, con respecto a los períodos siguientes, actuaciones como las de los obispos Marcelo, Teófilo o Porfirio dejan al descubierto, en especial en el caso de Porfirio con relación al templo de Zeus de Gaza, que su actuación pudo incluso haber llegado a incomodar al propio emperador ${ }^{73}$.

68 Una expresión de este tipo de aplicaciones puede verse en VILELLA, J.: «Cánones pseudoiliberritanos y Código Teodosiano: la prohibición de los sacrificios paganos», Polis, 17 (2005) pp. 97 ss.

${ }^{69}$ Más detalles en BUENACASA, C.: «La constitución y protección del patrimonio eclesiástico y la apropiación de los santuarios paganos por parte de la Iglesia en la legislación de Constancio II (337361)», pp. 229 ss.

70 IRMSCHER, J.: «La politica religiosa dell Imperatore Giustiniano contro i pagani e la fine della scuola neoplatonica ad Atene», CS, 11 (1990) pp. 579 ss.

71 Sobre la pervivencia del paganismo en Hispania ver, entre otros, SOTOMAYOR, M.: «Cristianismo primitivo y paganismo romano en Hispania», MHA, 5 (1981) pp. 173 ss.

72 Ver, por ejemplo, SARADI-MENDELOVICI, H.: «Christian Attitudes towards Pagan Monuments in Late Antiquity and their Legacy in Later Byzantine Centuries», DOP, 44 (1990) pp. 47 y 49.

${ }^{73}$ KLEIN, R.: «Distruzioni di templi nella Tarda Antichità. Un problema politico, culturale e sociale», $A A R C, 10$ (1995) pp. 134 y 139. 
Los ejemplos recogidos por las fuentes de información antiguas resultan muy numerosos ${ }^{74}$, a pesar de lo cual se nos hace muy difícil valorar hasta qué punto se haría efectiva la clausura de los espacios sagrados paganos, cuyos orígenes (o primeros intentos) pueden rastrearse ya en la época del emperador Constantino ${ }^{75}$.

En este contexto se documenta una regresión significativa del número de inscripciones referidas a las construcciones y/o restauraciones, bien de templos bien de ceremonias públicas paganas, en tiempos de Constantino y sus hijos en las ciudades romanas del Norte de África ${ }^{76}$.

No obstante, ello no significaría que la población africana de los centros urbanos se hubiera convertido en masa al cristianismo, abandonando al mismo tiempo las prácticas paganas tradicionales, sino simplemente que el control ejercido por las autoridades resultaba muy estricto ${ }^{77}$.

Por el contrario, la revitalización que se observa en ese territorio norteafricano en tiempos de Juliano y en los primeros años de los Valentinianos nos indicaría que el culto pagano no habría desaparecido, sino que se habría recluido en el interior de los domicilios privados ${ }^{78}$.

Tampoco podemos calcular el número de santuarios paganos que se convertirían en basílicas cristianas, aunque sabemos a este respecto que, de acuerdo con lo que se desprende del caso de Jorge de Alejandría, debía contarse con el permiso imperial para poder dar este paso.

Esta imprescindible licencia del emperador obedecería al hecho de que los templos paganos eran propiedad del Estado, de manera que sus patrimonios, en tanto que terrenos públicos, se inscribían en el marco de la res privata, la cual actuaría como intermediaria en la cesión de los mismos a la Iglesia.

Sin embargo, se constata claramente un intervencionismo activo por parte de los emperadores en la expoliación sistemática de los santuarios paganos.

Hemos de tener en cuenta, además que los problemas económicos ocasionados por las costosas campañas militares en que se verían envueltos los sucesores de Constantino les obligarían a buscar nuevos recursos para aprovisionarse de

${ }^{74}$ Ver, por ejemplo, los comentarios al respecto de FOWDEN, G. [«Bishops and Temples in the Eastern Roman Empire, A.D.320-345», JThS, 29 (1978) pp. 59-60].

75 BARNES, T. D.: «Christians and Pagans in the Reign of Constantius», L Église et I Empire au IVe siècle, Vandouevres-Genève, 1989, pp. 325-327

76 LEPELLEY, C.: Les cités de I Afrique romaine au Bas-Empire, París, 1979, 1, pp. 345-347.

77 Acerca de la creación del patrimonio de las iglesias norteafricanas, que no arranca de la época de Cipriano sino de las décadas finales del siglo III y a lo largo de toda la centuria siguiente, remitimos a BUENACASA, C.: «La creación del patrimonio eclesiástico de las iglesias norteafricanas en época romana (siglos II-IV): renovación de la visión tradicional», Antigüedad y cristianismo, 21 (2004) pp. 495 ss.

${ }^{78}$ En el caso del primero de dichos emperadores este renacimiento en cuanto a la recuperación de los santuarios paganos se extendería a todas las provincias del Imperio. Cf. ARCE, J.: «Reconstrucciones de templos paganos en época del emperador Juliano (361-363 d.C.)», RSA, 5 (1975) pp. 201 ss. 
metales, en especial oro, por lo cual no tendrían inconveniente en aprovecharse de los tesoros de los templos paganos ${ }^{79}$.

No resulta extraño, por tanto, que entre 342 y 350 el senador siciliano Julio Fírmico Materno animase a los emperadores a retirar las placas de oro y plata que adornaban las estatuas de madera de los ídolos paganos y a expropiar cuanto hubiera de valioso en dichos santuarios con el fin de utilizarlo en su propio beneficio (con vistas a la amonedación) ${ }^{80}$.

De la misma manera tampoco extraña que Juliano afirmase que los hijos de Constantino no sólo habían continuado la política paterna con respecto al saqueo de los templos paganos sino que, junto a ello, habían desarrollado al mismo tiempo una más amplia política destructiva de dichos recintos sagrados ${ }^{81}$.

En cualquier caso las iniciativas de los hijos de Constantino parecen haber sido anuladas muy pronto por la actuación de Juliano, cuya política religiosa al respecto se iba a manifestar radicalmente diferente.

Y, en ese ámbito de actuación, sabemos que Maximino Daia, coincidiendo con una etapa de parón en su persecución contra los cristianos, ordenaría que los antiguos templos paganos fueran reconstruidos ${ }^{82}$ (a continuación este hecho vendría seguido -agosto del 312- de la designación de sacerdotes encargados de la dirección y cultos de dichos recintos sagrados).

Pero es que no sólo los máximos representantes del poder romano sino también los miembros de sus cancillerías se hallaban dispuestos a profanar los santuarios paganos y obtener las ventajas económicas correspondientes, como nos documenta Amiano Marcelino con respecto a algunos de los miembros de la corte de Constancio $\|^{83}$.

\section{SITUACIÓN DE LAS PROPIEDADES ECLESIÁSTICAS Y SU FISCALIDAD SEGÚN EL CODEX THEODOSIANUS}

Sabemos que a comienzos del siglo V (Honorio y Arcadio), una vez fraguada por completo la alianza entre Estado romano e Iglesia oficial, lo que conllevaba una protección privilegiada y exclusiva de ésta, las iglesias de las principales ciudades del Imperio (Roma, Alejandría, Antioquía, Constantinopla...) dispondrían ya de importantes patrimonios fundiarios y propiedades territoriales.

79 CALLU, J. P.: «Problèmes monétaires du quatriéme siècle (311-395)», Transformations et conflicts au IVe siècle ap.J.C., Bonn, 1978, pp. 103 ss.

80 LO CASCIO, E.: «Aspetti della politica monetaria nel IV secolo», AARC, 10 (1995) pp. 481 ss.

81 Juliano, Orationes 7.228 b-c.

82 Euseb., HE 14.9. Ver igualmente Euseb., De mart. Pal. 9.2. Cf. MOLTHAGEN, J.: Der römische Staat und die Christen im zweiten und dritten Jahrhundert, Gotinga, 1975, página 116.

83 Res Gestae 22.11.5. Cf. SANTOS, N.: «Adivinación y magia en el siglo IV: Amiano Marcelino y la legislación imperial», Helmantica, 61 (2010) pp. 217 ss. 
En esta apropiación acumulativa de bienes de carácter inmobiliario habrían intervenido 3 factores distintos:

- por un lado que, desde tiempos de Constantino, las propiedades eclesiásticas gozarían de un conjunto de inmunidades con respecto a la exención de algunos impuestos más comunes;

- por otro, que los emperadores permitirían que la Iglesia pudiera apropiarse, poco a poco, del patrimonio de los herejes y de los bienes de los templos paganos;

- y, finalmente, el hecho de que las herencias testamentarias habían contribuido igualmente al aumento del patrimonio de la Iglesia en gran medida.

I. Pero, hagamos un poco de historia: como conocemos a través de EUSEBIO DE CESAREA ${ }^{84}$ y LACTANCIO ${ }^{85}$, a fines del 312 o inicios del 313 Constantino y Licinio se reunirían en Milán, a resultas de lo cual se decidió la devolución a los cristianos de sus lugares de reunión, así como también otras propiedades que pertenecían a sus comunidades ${ }^{86}$.

Esta restitución se realizaba a la Iglesia en cuanto colectivo jurídico, no a título de personas individuales, lo que significaba que se la reconocía como institución (LACTANCIO, De mort.pers. 48:... ad ius corporis eum, id est ecclesiarum, non hominum singulorum pertinentia).

Sin embargo, no había sido ésta la primera actuación del Estado romano permitiendo a la Iglesia adquirir y poseer propiedades: ya el edicto de Galieno del 260 le concedía el derecho de poseer bienes propios ${ }^{87}$, y medio siglo después (en el 311) los 4 tetrarcas del momento, con Galerio como Augustus senior, habían firmado el edicto de tolerancia con el que se ponía fin a la última de las persecuciones $\mathrm{y}$, sobre todo, se devolvían a la Iglesia sus propiedades ${ }^{88}$.

Pero la política de Constantino no iba a quedar en el mero reconocimiento de este derecho, sino que vendría acompañada de un conjunto de medidas a favor de la Iglesia cristiana.

En primer lugar destaca el hecho de que el emperador permitiría el restablecimiento libre de los lugares de culto de las iglesias cristianas, hasta entonces controladas por las ordenes emanadas de la corte (EUSEBIO DE CESAREA, Historia Eclesiástica 10.2.1-2).

84 HE 10.5.

85 De mort. persec. 48.

${ }^{86}$ Más detalles en FARINA, M.: L'Impero e I imperatore cristiano in Eusebio di Cesarea. La prima teologia politica del cristianísimo, Zurich, 1966.

87 Euseb., HE 7.13. Cf. KERESZTES, P.: «The Peace of Gallienus, 260-303 A.D.», WS, N.F. 9 (1975) pp. 174 ss.

${ }^{88}$ Lact., De mort. persec. 34. Cf. SEGA, I.: «L editto di Galerio del 311», Scritti Vassalini, Verona, 1974 , pp. 445 ss. 
A esa primera disposición favorable, e inmediata tras el reconocimiento del cristianismo como religión oficial, se unirían otras, como la orden de entregar 3000 foIles a Ceciliano, obispo de Cartago (EUSEBIO, HE 10.6.1-3), o la carta que el emperador remitió a Anulino, procónsul de África, que pronto adquiriría rango de ley, concediendo la exención de los munera civilia a todos los clérigos de la iglesia de dicho obispo ${ }^{89}$.

Unos años después (319) esta disposición adquiriría carácter general para todos los clérigos mayores de las iglesias no cismáticas (CÓDIGO TEODOSIANO $\mathrm{XVI}$.2.2), y en el 330 se haría extensiva a los clérigos menores, es decir lectores, subdiáconos y otros clerici (CÓDIGO TEODOSIANO XVI.2.7).

Paralelamente a esta consecución de la inmunidad personal los clérigos procedieron a buscar la exención de impuestos para las propiedades que administraban: de esta manera, solo 2 años después de liberarles de los munera civilia, Constantino reconocería la inmunidad de los bienes fundiarios para los pertenecientes a la Iglesia y a la res privata (CÓDIGO TEODOSIANO XI.1.1).

Y estas medidas se verían completadas con la ley del año 321 (CÓDIGO TEODOSIANO XVI.2.4), por la que se permitía a la Iglesia poder ser establecida heredera por testamento, lo que supondría su implantación como fuente de patrimonio.

Todo ello implicaría un comportamiento diferente del Estado romano con respecto a herejes y paganos en relación con los años anteriores: Constantino, haciendo gala de una política cauta, se limitó a clarificar, con respecto a los donatistas, que debía privárseles de los privilegios de que gozaba la Iglesia oficial (CÓDIGO TEODOSIANO XVI.5.1 (año 326), mientras que a los novacianos les permite mantener sus iglesias (CÓDIGO TEODOSIANO XVI.5.2 (año 326) ${ }^{90}$.

En cuanto a los paganos, la situación no estaba aún madura para actuar abiertamente contra ellos y sus templos: las únicas leyes que hacen referencia a la religión pagana es para prohibir la aruspicina (CÓDIGO TEODOSIANO IX.16.1 (año 319); IX.16.2 (319); IX.16.3 (318) y XVI.10.1 (321).

La documentación antigua muestra una actitud un tanto más hostil hacia la religión pagana por parte del Estado, aunque no debemos olvidar que la mayor parte de las noticias provienen de la Vita Constantini de Eusebio y de otros historiadores eclesiásticos, como Jerónimo, Orosio, Sócrates o Sozomeno.

A este respecto la nueva actitud del Estado estaría representada por la prohibición del culto pagano ${ }^{91}$, así como por el saqueo y destrucciones de sus templos y espacios sagrados.

89 Euseb., HE 10.7.1-2 y CÓDIGO TEODOSIANO XVI.2.1.

90 Más detalles en ESCRIBANO, M. V.: «Herejía y poder en el siglo IV», La conversión de Roma. Cristianismo y paganismo, Madrid, 1990, pp. 151 ss.

91 Eusebio menciona (Vita Constantini 2.45) una prohibición imperial a propósito del sacrificio a los ídolos y de la erección de estatuas a los dioses, que no se recoge en el Codex Theodosianus. 
En este sentido la confiscación de los templos y santuarios paganos no debe resultarnos extraña en el marco de la historia del Imperio, puesto que Calígula, Nerón, Maximiliano o Majencio habían recurrido a ello, especialmente en épocas de crisis monetaria en las que escaseaban los metales preciosos, y en ese contexto Constantino tendría una gran necesidad de oro, dado que una de sus reformas fiscales implicaba la acuñación de una moneda de oro, el solidus aureus.

Por lo que se refiere a las destrucciones de templos paganos el testimonio de Eusebio pretende mostrar una Iglesia cristiana que triunfa en todas las partes del Imperio merced al apoyo imperial.

Sin embargo, de acuerdo con las indicaciones de L. DE GIOVANNI ${ }^{92}$ con respecto al supuesto edicto de Constantino acerca de la destrucción de los templos paganos, considera que, de haber sido emitido realmente por dicho emperador, no se evidencia en las fuentes una aplicación rigurosa e inmediata al respecto (a su juicio Constantino habría preferido combatir la religión pagana en el plano de las denuncias formales antes de recurrir a medidas coercitivas).

Por su parte G. BONAMENTE es de la opinión de que, si bien serían pocos en número los templos derruidos, es posible referirse a una expoliación sistemática de la ornamentación y las estatuas de culto de los mismos ${ }^{93}$.

A partir de aquí no es posible referirse a una actuación sistemática por todos los territorios del Imperio en la que se declarase la clausura o destrucción generalizada de los edificios de culto pagano.

Como corroboración de esta idea disponemos, además, del testimonio de Libanio ${ }^{94}$ en el sentido de que, durante el reinado de Constantino, en los templos paganos reinaba la pobreza, a pesar de que se podía asistir al cumplimiento de todos los ritos.

De cualquier forma los escasos testimonios acerca de las destrucciones ordenadas por el emperador se refieren a los santuarios de Afaca y Heliópolis en Fenicia ${ }^{95}$, así como de Agai en Cilicia ${ }^{96}$ y a unas edificaciones paganas de Jerusalén y Mambré ${ }^{97}$.

En el caso de las tres primeras es posible hallar una justificación sagrada a dicha actuación, como consecuencia de la dudosa moralidad de los cultos a los que daban acogida (y en ese sentido se pronuncia Eusebio).

Por su parte los edificios de Jerusalén y Mambré serían arrasados con un fin claramente cristiano, puesto que en su lugar se construirían las basílicas programadas por Constantino, en el marco de su política de construcción de abundantes

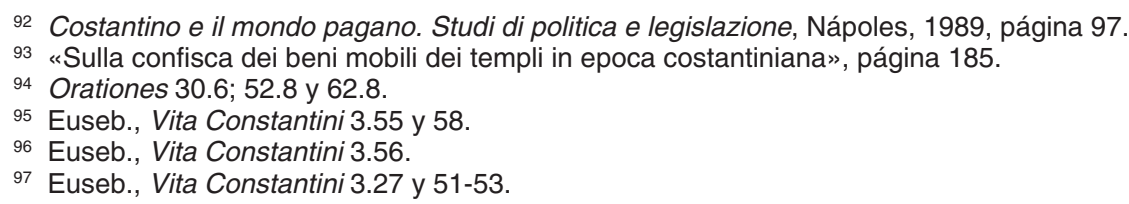


iglesias en muchas ciudades del Imperio [EUSEBIO DE CESAREA, Vita Constantini 3.43 (Belén); 3.43 (Monte de los Olivos): 3.48-49 (Constantinopla); 3.50 (Nicomedia); 3.50 (Antioquía) $]^{98}$.

Esta política constructiva de Constantino pretendía mostrar a todos los súbditos del Imperio, tanto si eran cristianos como paganos, que el emperador ponía bajo su protección a la nueva religión, sin olvidar el hecho de que consideraría a los edificios eclesiásticos como una herramienta más para manifestar y promover sus intenciones políticas ${ }^{99}$.

Dichas iglesias hallarían emplazamiento en terrenos de la res privata, tanto si habían sido cedidos por el emperador como si, y tal era el caso de Jerusalén y Mambré, se alzaban sobre el solar de un templo pagano reivindicado por la res privata con anterioridad a su entrega a la Iglesia (EUSEBIO DE CESAREA, Vita Constantini 3.65) ${ }^{100}$.

Además de este tipo de intervenciones, calificables como «oficiales», tenemos constancia de otras actuaciones de carácter «espontáneo», explicables en el contexto del fervor popular y sin conexión alguna con un programa estatal de alcance más amplio ${ }^{101}$.

De esta manera, es posible afirmar que la política antipagana de Constantino no tendría un carácter sistemático, sino que se hallaría encaminada a difundir un mensaje muy claro: mostrar el favor imperial respecto al cristianismo e impulsar fuertemente su propagación.

II. Tras la intervención constantiniana la evolución del Imperio y de la Iglesia seguirían un camino algo diferente al de los 3 primeros siglos de su existencia: los hijos de Constantino continuarían, con muy escasas variantes, la política de favorecer a la Iglesia cristiana iniciada por su padre ${ }^{102}$.

Así, por ejemplo, en el año 353 Constancio Il y Constante renuevan la exención de los clérigos de los munera civilia, al tiempo que les reconocen el derecho a no pagar el impuesto sobre las actividades comerciales, con el objetivo de que los beneficios que de ello se derivasen redundasen en la asistencia a los necesitados (CÓDIGO TEODOSIANO XVI.2.10).

98 Acerca de la actividad edilicia cristiana desplegada por Constantino, y en especial sobre las iglesias erigidas en Roma, remitimos a ALZATI, C. [«La Chiesa nell Impero e I imperatore nella Chiesa», L impero romano-cristiano: problemi politici, religiosi, culturali, Roma, 1991, pp. 194-198].

99 KRAUTHEIMER, R.: «The Ecclesiastical Building Policy of Constantin», Costantino il Grande, Macerata, 1993, pp. 513 ss.

100 El testimonio de Eusebio resulta sumamente interesante, puesto que en el Codex Theodosianus no hallamos recogida ninguna disposición acerca de este extremo hasta la época de Valentiniano I y Valente.

101 Se explicaría así el resto de las destrucciones de templos documentadas por Eusebio en Fenicia (Vita Constantini 4.39).

102 Ver, entre otros, BOVE, L.: «Inmunità fondiaria dei chiese e chierici nel Basso Impero», pp. 887-894. 
Pero la situación privilegiada de la Iglesia desde el punto de vista fiscal se recortaría en los años finales de Constancio II: tras el concilio de Rímini, al que aistieron al parecer unos 400 obispos, procedentes de África, Britania, las Galias, Hispania, Iliria e Italia, quienes solicitarían del emperador la concesión de la inmunidad completa de los fundi eclesiásticos, el soberano recorta con la ley del 360 (CÓDIGO TEODOSIANO XVI.2.15) los privilegios que en materia comercial se habían otorgado a los clérigos con anterioridad.

Además, dicha constitución imperial parece hacer una distinción clara entre los bienes que se hallaban bajo la administración de la Iglesia y los que formaban parte del patrimonio personal de obispos y clérigos, concediéndose la inmunidad únicamente a los primeros.

Los siguientes emperadores confirmarían igualmente este sentido restrictivo, hasta el punto de que la Iglesia acabaría pagando el impuesto fundiario sobre sus propiedades, puesto que, en caso contrario, no resulta comprensible que el emperador Teodosio II considere un hecho excepcional que la iglesia de Tesalónica se vea exenta del pago de la capitatio-iugatio en el 424.

Ahora bien, pese a este fracaso relativo por lograr una inmunidad total con respecto a sus bienes, la Iglesia cristiana seguiría incrementando su patrimonio a través de la otra vía que se le ofrecía, la política imperial contra herejes y paganos.

Constancio II no parece haber tomado nuevas medidas legales contra los primeros, aunque sí contra los segundos, a pesar de que las consecuencias de la aplicación de dicha legislación serían anuladas muy pronto por su sucesor Juliano, cuya política religiosa se mostraría diametralmente opuesta ${ }^{103}$.

Ninguna ley emitida por dicho emperador ha llegado hasta nosotros, aunque resulta fácil suponer que entregaría (o, más bien, restituiría) numerosos bienes a los templos paganos ${ }^{104}$, puesto que, al finalizar su reinado, y el de su efímero sucesor, Joviano, cuando ya se hallaban en el trono Valentiniano I y Valente, éstos se apresuraron a revocar por dos veces en un mismo año todas las donaciones que el último representante de la familia de Constancio había llevado a cabo, con el objetivo de reintegrarlas a la res privata (CÓDIGO TEODOSIANO X.1.8 y V.13.3 (del año 364) ${ }^{105}$.

Por ello es posible pensar que Constancio II incorporaría una cantidad notable de los bienes de los templos paganos a la res privata, patrimonio que no habría sido entregado a la Iglesia sino que el emperador se lo asignaría en beneficio propio.

103 DIMAIO, M.: «The Emperor Julian Edicts of Religious Toleration», AncW, 20 (1989) pp. 99 y ss. Cf. SANTOS, N.: «Juliano y Teodosio», Héroes y antiheroes en la Antigüedad clásica, Madrid, 1997, pp. 267 ss.

104 DURLIAT, J.: Les finances publiques de Dioclétien aux Carolingiens, página 54.

105 PERGAMI, F.: La legislazione di Valentiniano e Valente (364-375), Milán, 1993, pp. 7 y 123. 
Como consecuencia de ello Juliano dispondría de los medios y mecanismos legales y administrativos suficientes para poder llevar a cabo dicha restitución, y además de forma rápida ${ }^{106}$.

Sin embargo, su reinado sería demasiado breve como para poder forzar a la Iglesia a devolver cuanto había recibido de los emperadores que le habían precedido en el poder, por lo que su actuación se reduciría a lo que él controlaba directamente sin impedimento de ningún tipo, es decir los bienes integrados en la res privata.

III. De ahí que solamente los emperadores Valentiniano I y Valente se sintieran damnificados y en ningún momento (ni documento) se refieran a la restitución de lo que se hubiera enajenado a la Iglesia ${ }^{107}$.

No obstante, la actuación de Juliano sería aprovechada por algunos sectores de la sociedad romana para crear confusión, situación que debió prolongarse durante bastante tiempo puesto que en el 370 Valentiniano I y Valente todavía necesitaban aclarar que la legislación vigente era la que existía a finales del reinado de Constancio II (CÓDIGO TEODOSIANO XVI.2.18), al igual que cuando en el año 400 Honorio dirige a los donatistas una ley descalificando el edicto que éstos dicen tener de Juliano (CÓDIGO TEODOSIANO XVI.5.37).

Estos dos emperadores hermanos ordenarían igualmente que fueran confiscados los lugares de reunión de los maniqueos en Roma (CÓDIGO TEODOSIANO XVI.5.3 (año 372), aportando disposiciones similares con respecto a las iglesias de los herejes en 2 leyes posteriores, cuando, una vez muerto Valentiniano, reinan Graciano y Valentiniano II en Occidente y Valente en Oriente.

A través de una de tales leyes solamente se nos indica que dichas iglesias serían incorporadas al fisco (CÓDIGO TEODOSIANO XVI.5.4 (año 376 o 378), mientras que en la otra se ordena expresamente que sean restituidas a la Iglesia católica (CÓDIGO TEODOSIANO XVI.6.2 (año 377) ${ }^{108}$.

Nos encontramos, por tanto, ante 2 disposiciones próximas en el tiempo que ilustran una costumbre que, según Eusebio, venía produciéndose desde la época de Constantino.

Además, se sancionaba de manera legal que la secuencia lógica por la que las tierras pasaban a la Iglesia era teniendo como intermediaria a la res privata.

Por otro lado, estos 3 emperadores confirmarían igualmente la exención de los munera civilia para todos los miembros de la jerarquía eclesiástica (CÓDIGO TEOSODIANO XVI.2.24 (año 377).

106 OIKONOMIDES, A. N.: «Ancient Inscriptions recording the Restoration of Greco-Roman Shrines by the Emperor Flavius Claudius lulianus (361-363 A.D.)», AncW, 15 (1987) pp. 198 ss.

107 Sobre la política religiosa de Valentiniano remitimos, por ejemplo, a ROUGÉ, J.: «Valentinien et la religión: 364-365», Ktèma, 12 (1987) pp. 285 ss.

108 DE GIOVANNI, L.: Chiesa e Stato nel Codice Teodosiano, pp. 87 ss. 
IV. Sin embargo, el paso decisivo hacia una política estatal favorable completamente a los cristianos y en contra de los herejes y paganos se observa, desde el punto de vista legislativo, en el momento en que, poco tiempo después de la muerte de Valente, Graciano asocia al trono como Augusto a Teodosio en el año $379^{109}$.

Este último emperador, como gran benefactor de la Iglesia, convirtió al Imperio romano en un Estado que profesaba la fe de Nicea: como muestra de ello no sólo emitiría el edicto de Tesalónica del año 380 (CÓDIGO TEODOSIANO XVI.1.2) ${ }^{110}$ sino que ambos emperadores renunciarían a ostentar el título de pontifex maximus por sus connotaciones paganas.

Junto a ello los cristianos se verían confirmados en sus privilegios y apoyados con toda la fuerza del Estado; por ello no debe extrañarnos que se confirme, a través de una nueva constitutio, la exención de los munera civilia para todos los clérigos (CÓDIGO TEODOSIANO XVI.2.26 (año 381) y que se promulguen 2 nuevas leyes para regular las exenciones de que gozaban los fundi eclesiásticos (CÓDIGO TEODOSIANO XI.16.15 (año 382) y XI.16.18 (año 390) ${ }^{111}$.

Tras la publicación del edicto de Tesalónica iba a surgir una nueva concepción del hereje ${ }^{112}$, dado que los objetivos del Estado romano y de la Iglesia son los mismos y ello supone la condena de cuantos se oponen a la fe de la Iglesia oficial.

A este respecto las disposiciones del Codex Theodosianus lo confirman plenamente: de las 76 constitutiones que configuran el tomo $\mathrm{V}$ del libro $\mathrm{XVI}$ las que se incluyen con los números 5 a 24 corresponden a Teodosio.

Entre dichas disposiciones destacan:

— la expulsión de los herejes de las ciudades (CÓDIGO TEODOSIANO XVI.5.11 (año 383);

- la prohibición de tener obispos y sacerdotes, así como de contar con lugares de reunión propios (CÓDIGO TEODOSIANO XVI.4.2 y 5.14 (año 388) ${ }^{113}$;

- o la imposibilidad de testar, de recibir herencias o, incluso, de tener propiedades (CÓDIGO TEODOSIANO XVI.5.17 (año 389).

Las consecuencias jurídicas resultaban evidentes: al privárseles de todo derecho civil perderían igualmente el de la posesión de bienes.

Se explica, a partir de aquí, que, en la constitutio en la que Teodosio confirma los resultados del concilio de Constantinopla del 381 , se ordene entregar todas las

109 CÓDIGO TEODOSIANO XVI.5. (año 379), que condena en bloque las herejías y prohíbe su enseñanza en público.

110 JOANNOU, P.P.: La législation imperiale et la chrsitianisation de I Empire (311-476), pp. 44-46.

111 VERA, D.: «Teodosio I tra religione e politica: i riflessi della crisi gotica dopo Adrianopoli», $A A R C 6$ (1986) pp. 223 ss.

112 ESCRIBANO, M. V.: «Herejía y poder en el siglo IV», pp. 151-154.

113 ESCRIBANO, M. V.: "De his qui super religione contendunt. la constitutio 16,4,2 (388) del Codex Theodosianus», Antiquité Tardive, 13 (2005) pp. 265 ss. 
iglesias ocupadas por los herejes a los obispos que profesaban la fe de Nicea (CÓDIGO TEODOSIANO XVI.1.3 -año 381-) sin que en esta ocasión se haga mención alguna a la mediación de la res privata ${ }^{114}$.

A pesar de que esta ley encontraría en un primer momento una oposición notable, en numerosas ciudades del Imperio llegaría a aplicarse efectivamente y permitiría que las iglesias locales aumentaran considerablemente sus posesiones ${ }^{115}$.

En este contexto Teodosio creyó llegado igualmente el momento de actuar contra los paganos, prohibiendo su ancestral religión mediante la promulgación de 3 constitutiones (CÓDIGO TEODOSIANO XVI.10.10 (año 391); XVI.10.11 (año 391) y XVI.10.12 (año 392).

Y ello a pesar de que el emperador se había mostrado dispuesto a que los paganos conservaran aquellos templos que tuvieran un cierto valor artístico, como era el caso del santuario de Edesa, cuya conservación legisla el más alto cargo del Estado (CÓDIGO TEODOSIANO XVI.10.8 (año 382).

Pero, junto a ello, la propia documentación del Código Teodosiano, así como los fragmentos de algunos otros testimonios, parecen demostrar que la causa de la decadencia del paganismo romano no sería el desinterés puesto de manifiesto por la población sino una legislación que lo convertía a todas luces en algo impracticable ${ }^{116}$.

Así pues, aunque durante el reinado de Teodosio la propiedad de los herejes había encontrado una vía legal para ser asimilada en el marco de los patrimonios de las iglesias nicenas, no sucedería lo mismo todavía con respecto a los patrimonios de los templos paganos ${ }^{117}$.

Sin embargo, el paganismo había recibido ya el golpe de gracia, por lo que no es de extrañar que en el año 396 los hijos y sucesores de Teodosio (Arcadio en Oriente y Honorio en Occidente) abolieran los privilegios de los sacerdotes paganos (CÓDIGO TEODOSIANO XVI.10.14), y en los años siguientes ordenaran la clausura de sus templos:

— en el 397 se promulgó que el material proveniente de la demolición de los templos se utilizara en la reparación de murallas, puentes, vías y acueductos (CÓDIGO TEODOSIANO XV.1.36);

- en el 399 se dispuso que los templos rurales fueran derruidos sin disturbios ni tumultos (CÓDIGO TEODOSIANO XVI.10.16);

114 J.DURLIAT, por ejemplo, propone una fecha más tardía para este suceso basándose para ello en CÓDIGO TEODOSIANO XVI.5.57 (año 415).

115 SANTOS, N.: «Teodosio y el reconocimiento del cristianismo», Congreso Internacional: la Hispania de Teodosio, Segovia, 1998, pp. 241 ss.

116 Para más detalles ver, entre otros, FRASCHETTI, A.: «Principi cristiani, templi e sacrifici nel Codice Teodosiano e in altre testimonianze parallele», Diritto romano e identità cristiana, Roma, 2005, pp. 123 ss.

117 MURGA, J. L.: «El expolio y deterioro de los edificios públicos en la legislación post-constantiniana», $A A R C, 3$ (1979) pp. 239 ss. 
- e igualmente en ese mismo año que los templos paganos desprovistos de ornamentos fueran clausurados, pero respetados (CODDIGO TEODOSIANO XVI.10.18).

La legislación contra los santuarios paganos culmina en el año 401, momento en que los emperadores deciden que los edificios pertenecientes a los templos que se hallasen en el interior de los cascos urbanos o junto a las murallas quedaran en manos de los decuriones y que fueran ellos quienes se ocupasen de las peticiones de quienes los reclamasen (CÓDIGO TEODOSIANO XV.1.41 (año 401) ${ }^{118}$.

Así pues, es posible pensar que de esta manera se abría la vía legal para que la Iglesia entrara en posesión de dichos reductos y edificios.

\section{CONCLUSIONES}

Como resumen, hemos tratado de demostrar en las páginas precedentes que, en la misma medida en que el Estado imperial romano iba consintiendo y protegiendo cada vez más los patrimonios de la Iglesia cristiana (incluso con una fiscalidad, en un primero momento baja y después casi nula), procedía a desproteger las propiedades pertenecientes a los paganos y herejes, lo que acabaría repercutiendo finalmente en beneficio de los primeros ${ }^{119}$.

El proceso, no obstante, se desarrollaría de forma lenta, puesto que daría comienzo con Constantino y solamente acabaría consolidándose con Teodosio y, de manera especial, con los miembros de la dinastía por él fundada ${ }^{120}$.

Durante la primera de estas fases la Iglesia hallaría sin duda una facilidad mayor en asimilar los patrimonios de las iglesias rivales, es decir de las de los herejes.

Frente a ello la ocupación cristiana de los templos paganos resultaría mucho más difícil y se desarrollaría con posterioridad, durante el reinado de los sucesores de Teodosio ${ }^{121}$.

La situación, en los momentos finales del siglo IV y en los iniciales de la centuria siguiente, no sería más que el resultado de la gran compenetración de intereses existente entre la Iglesia cristiana y el Estado romano.

Como consecuencia de ello los miembros del orden episcopal gozarían de una situación privilegiada, que les permitía desplegar una política de agresión contra los

118 En esta misma dirección se manifiesta una ley del 408 (CÓDIGO TEODOSIANO XVI.10.9), edictada cuando Arcadio había asociado ya al trono a su hijo Teodosio II, a través de la cual se indicaba que los templos paganos serían destinados a uso público.

119 PASCHOUD, F.: «L Église dans I Empire romain. Tendances dans I Église contre et pour I Empire», Actes VIle Congrès International d Études Classiques, Budapest, 1984, pp. 197 ss.

120 ERRINGTON, R. M.: «Christian Accounts of the Religious Legislation of Theodosius I», Klio, 79 (1997) pp. 398 ss.

121 BUENACASA, C.: «La decadencia y cristianización de los templos paganos a lo largo de la Antigüedad tardía (313-423)», Polis, 9 (1997) pp. 25 ss. 
paganos de los centros urbanos en los que ejercían su autoridad como representantes superiores de la jerarquía cristiana.

El resultado inmediato de dicha actuación no podía ser otro que la cristianización paulatina de los templos y espacios sagrados más representativos del territorio ocupado por las comunidades que se hallaban bajo sus órdenes.

Sin embargo, no podemos olvidar que un proceso de esta naturaleza, cuyos orígenes hay que hacer remontar a la época de Constantino, y que únicamente se vería interrumpido durante un breve espacio de tiempo por Juliano, acabaría por convertirse en un elemento básico para incrementar cada vez más el patrimonio eclesiástico.

De esta manera los miembros de la dinastía teodosiana ${ }^{122}$, fieles al pacto de alianza iniciado por su padre entre el Estado romano y la Iglesia, permitirían acontecimientos tales como la solemne consagración del principal templo pagano de la ciudad de Cartago, el dedicado a Dea Caelestis, como basílica paleocristiana bajo el obispo Aurelio ${ }^{123}$.

Este hecho tendría lugar ya en una fecha entre los años 399 y 407, es decir muy poco tiempo después de la promulgación del edicto que ordenaba, por última vez y de manera definitiva, el cierre de los edificios de culto pagano.

Por otro lado, a medida que avanzamos en el siglo $\mathrm{V}$ y el poder político en Roma decae enormemente, asistiremos a un auge cada vez mayor del patrimonio y del poder de la Iglesia.

122 SANTOS, N.: «Mujeres hispanas y poder en la corte del emperador Teodosio: la génesis de una dinastía», Homenaje a Julio Mangas en su 70 aniversario (en prensa).

${ }_{123}$ QUODVULTDEUS, Liber de promissionibus et praedictionibus Dei 3.38.44. Para más detalles remitimos a SALINERO, R.: Poder y conflicto religioso en el Norte de África: Quodvultdeus de Cartago y los vándalos, Madrid, 2002. 
